\section{Research Article}

(C) 2022 Badawi et al. This is an open access article licensed under the Creative Commons Attribution-NonCommercial 4.o International License

(https://creativecommons.org/licenses/by-nc/4.o/)

\title{
The Linkage of Perceived CSR, Corporate Reputation, Organizational Commitment, and Purchase Intention
}

\author{
Badawi $^{1}$ \\ Ali Jufri ${ }^{1}$ \\ Tri Budi Prasetyo ${ }^{1}$ \\ Puspa Dewi Yulianty \\ Imam Hadiwibowo \\ Arif Nurudin ${ }^{1}$ \\ Muafi $^{\mathbf{2}^{*}}$ \\ Tania Avianda Gusman ${ }^{3}$ \\ ${ }^{1}$ Universitas Muhammadiyah Cirebon, West Java, 45153, Indonesia \\ ${ }^{2}$ Universitas Islam Indonesia, Daerah Istimewa Yogyakarta 55283, Indonesia \\ ${ }^{3}$ Osaka University, 1-1 Machikaneyama, Toyonaka, Osaka 56o-oo43, Japan \\ ${ }^{*}$ Corresponding Author
}

DOI: https://doi.org/10.36941/ajis-2022-0036

\section{Abstract}

The ongoing pandemic has resulted in various parties being affected both economically and socially. This makes social issues become very sensitive. For companies, efforts that can be made to help deal with the pandemic while improving performance are CSR (corporate social responsibility). Some literature proves the positive influence of CSR on company reputation, organizational commitment, and purchase intention. Therefore, this study aims to analyze the relationship between perceived CSR to company reputation, organizational commitment, and purchase intention. The type of this study is quantitative research with primary data obtained through distributing questionnaires on 310 employees in the Indonesian cement industry. The data analysis in this study is carried out using a structural equation modeling with SmartPLS software. The results of the analysis show that perceived CSR has a significant influence on corporate reputation, organizational commitment, and purchase intention. The findings also prove that there is a significant influence of corporate reputation and organizational commitment on purchase intention. This research also provides some strategic suggestions for companies in the cement industry to improve their reputation, commitment, and purchase intention of their consumers. This study contributes to broader exploration of a research model related to the positive impact of CSR on the company's internal aspects, namely organizational commitment and purchase intention, and external aspect, namely the corporate reputation.

Keywords: Perceived CSR, Corporate Reputation, Organizational Commitment, Purchase Intention, Cement Industry 


\section{Introduction}

There are several aspects that are considered by consumers when purchasing a product, one of which is the value owned by the company. In forming positive values by consumers, one aspect that must be optimized is corporate social responsibility (CSR) (Bianchi et al. 2019). Some companies implement CSR as a strategy and management to increase competitive advantage (Motilewa \& Worlu, 2015) and market share (Bianchi et al. 2019; Aksak et al., 2016). CSR is a form of efforts made by companies to have a positive impact on the environment and social, as well as to establish communication with stakeholders to gain their support through a transparent and ethical process (Taghian et al., 2015). The practice of CSR is in line with the concept introduced by Eklington (1997) that there are 3 main dimensions of corporate responsibility known as the triple bottom line concept, namely profit (seeking profit), people (empowering the community), and planet (empowering nature conservation) (Henry et al., 2019). On the other hand, from the external side, good CSR implementation is able to provide a good reputation for the company (Bianchi et al. 2019; Verčič \& Orić, 2018). CSR is able to provide a good image for the company in the eyes of the community. One of the industries in Indonesia that aggressively provides CSR funds is companies in the cement industry. For example, PT Semen Gresik, which in 2020 allocated CSR funds as an effort to quickly respond to the Covid-19 pandemic, whose budget reached IDR 3.724 billion. In several empirical studies, it is proven that CSR is able to have a positive impact on companies. These impacts arise not only from external companies that provide feedback but also from internal companies that are getting better. There are several internal aspects of the company which performance is supported by CSR, one of which is organizational commitment (Roudaki \& Arslan, 2017). Organizational commitment represents a good relationship between employees and the company. The good image of the company that arises because of CSR will be able to strengthen employee loyalty to the company. A sense of pride and belonging by employees is a separate strength for the company. Various empirical studies have analyzed the positive impact of CSR, but they are still focused on one side, namely internal and external aspects. This study will conduct broader exploration in a research model related to the positive impact of CSR on the company's internal aspects, namely organizational commitment and purchase intention, and company's external aspect, namely the corporate reputation.

\section{Literature Review}

\subsection{Perceived CSR on Corporate Reputation}

CSR is one of the company's activities that gets high appreciation from the community. During the pandemic conditions since the beginning of 2020, many CSR funds from various companies have been allocated for handling the COVID-19 outbreak. This is very helpful for both the community and the government. On the other hand, environmental responsibility is one of the strategies for companies to form a positive image for the company. Organizations that develop strategies, policies, and practices related to social responsibility have higher levels of perceived reputation (Verčič \& Orić, 2018). Javed et al. (2020); Aksak et al., (2016); Vishwanathan et al. (2020); Rehman et al. (2020); and Kucharska (2020) found empirical evidence that CSR disclosure will be able to have a positive impact on the corporate reputation. Meanwhile, Pham \& Tran (2020) found that company reputation was able to mediate the relationship between CSR and company performance. Creating a good reputation means connecting the company's internal management with external expectations. External expectations always expect environmental and social welfare (Verčič \& Orić, 2018). Bianchi et al. (2019) explained that perceived CSR is able to have a positive impact on companies both in the long and short term. The short-term impact is purchase intention, while the long-term impact is the corporate reputation. CSR activities consist of four dimensions, namely discretionary, ethical, legal, and economic CSR (Lee, 2020). The implementation of good CSR activities will foster prestige for employees. This prestige arises because the corporate reputation increases in the public eyes' (Lee, 
2020). The form of CSR implementation refers to the company's three main responsibilities, namely providing economic, social, and environmental benefits (Tangnisalu et al., 2020). Optimal CSR and organizational justice provide a reliable and positive domino effect in increasing employee trust and company reputation (Tangnisalu et al., 2020). This shows that perceived CSR in theory and the results of previous studies are proven to be able to improve the corporate reputation.

H1: Perceived CSR has a positive and significant effect on corporate reputation

\subsection{Perceived CSR on Organizational Commitment}

The social performance of a company will foster enthusiasm and work motivation for employees (Khaskheli et al., 2020). These conditions will form optimal and effective employee performance. Various literatures agree that CSR is a company strategy in creating long-term profits (Bianchi et al., 2019). In addition, it is also able to provide short-term benefits such as organizational performance (Nguyen \& Tu, 2020) and employee commitment to the company (Ahmad et al., 2020; George et al., 2020). Several literatures have empirically proven the relationship between CSR and organizational commitment (Ahmad et al., 2020; Bianchi et al., 2019; Roudaki \& Arsland, 2017). George et al. (2020) added that the relationship between CSR and organizational commitment can be mediated by organizational trust and organizational identification. Konte et al. (2020) found that there is a relationship between CSR and organizational commitment. This relationship can be moderated by the need to belong and mediated by person-organization fit (Konte et al., 2020). Nguyen et al. (2020) emphasized that as the times develop, the company's responsibility is not only to stakeholders and shareholders, but it also extends to the environment and society. The high increase in the number of companies must be balanced with environmental stabilization, therefore CSR is a solution so that environmental sustainability and community welfare remain in the midst of increasing industrial development. Choi et al. (2020) analyzed organizational commitment in two generations, namely the millennial generation and the earlier generation. It was found that commitment is easier to form for the earlier generation than millennials. In forming a commitment to millennials, efforts can be made through shared decision making (Choi et al., 2020). Organizational commitment can be anticipated and enhanced by psychological elements, one of which is CSR. This is because CSR is able to increase the sense of compatibility and conformity of employees with company values (Konte et al., 2020).

$\mathrm{H}_{2}$ : Perceived CSR has a positive and significant effect on organizational commitment

\subsection{Perceived CSR on Purchase Intention}

CSR can be interpreted as an agreement between the social environment and the company. However, it can also be understood as a social demand that must be faced by companies if they want to exist (Hoang et al., 2020). The benefits obtained from CSR activities are not only for the community, as companies also benefit from CSR, one of which is an increase in purchase intention from consumers (Dang et al., 2020; Hoang et al., 2020). Consumer interest in buying a product or service is influenced by various factors, such as the company's social role. Social issues are very sensitive these days. The existence of the COVID-19 pandemic has also triggered public sympathy and respect for companies that are willing to provide assistance to affected parties (Cyfert et al., 2021). Therefore, CSR at this time is not only a social activity but also as a strategy to improve reputation and can lead to increased sales. Some literature proves that there is indeed a significant influence of CSR on purchase intention (Dang et al., 2020; Hoang et al. 2020; Cheng et al. 2021; Gupta et al. 2021). Alniacik et al. (2020) found that the relationship between CSR and purchase intention can be strengthened by the presence of a personal value orientation. A different finding was put forward by Gupta \& Wadera (2020) that in the fast-moving-consumers-goods sector CSR does not have a significant impact on purchase intention. The role of CSR perception in increasing sales does not only apply in the goods industry but also in the service industry. Ahn \& Kwon (2020) found that in the hotel industry, perceptions of CSR were able to increase the number of visits through increased trust and commitment. The role of CSR is not 
only in the company's offline activities but also in the company's online activities. Cheng et al. (2021) found a significant role of CSR on e-WOM and purchase intention.

$\mathrm{H}_{3}$ : Perceived CSR has a positive and significant effect on purchase intention.

\subsection{Corporate Reputation on Purchase Intention}

Reputation is one of the key components to increase products competitiveness, both goods and services (Balakrishnan \& Foroudi, 2020; Qalati et al. 2021). The influence of reputation will be stronger if it is balanced with the use of social media (Balakrishnan \& Foroudi, 2020). Therefore, creating a reputation must be taken seriously by the company because the impact is very significant on purchase intention. Qalati et al. (2020) found that the role of corporate reputation can be moderated by trust and perceived risk. Therefore, in increasing the role of reputation, efforts can be made with several things such as social media marketing (Balakrishnan \& Foroudi, 2020), website quality, trust, and perceived risk (Qalati et al. 2021). There are two types of reputation, namely positive reputation and negative reputation. A positive reputation really helps the company while a negative reputation will decrease the company's performance. Companies expect a positive reputation, because in addition to improving performance and purchase intention, a positive reputation can reduce or even eliminate the effects of a negative reputation on other aspects of the company (Jung \& Seock, 2016). In this digital era, the fate of a company is very dependent on reputation. The rapid spread of information allows information to trigger the bankruptcy of a business or even trigger an increase in company profits (Javed et al. 2020). Therefore, a number of new marketing methods have emerged such as viral marketing (Divya \& Evanita, 2021), E-WOM (Cheng et al. 2021) and others. Several previous literatures support the influence of reputation on purchase intention (Balakrishnan \& Foroudi, 2020; Qalati et al., 2021; Javed et al., 2020; Bianchi et al., 2019). Kim \& Oh (2020) found that in the fashion industry there are two variables that can increase purchase intention, namely sustainability level and brand reputation. As for the food industry, Balakrishnan \& Foroudi (2020) found a significant effect of reputation on purchase intention.

$\mathrm{H}_{4}$ : Corporate reputation has a positive and significant effect on purchase intention.

\subsection{Organizational Commitment on Purchase Intention}

Organizational commitment refers to the actions, policies, and activities of the organization that reflect employee care and satisfaction (Abduloh et al. 2020). Ahakwa et al. (2021) described organizational commitment as a method used by organizations to bind employee loyalty and reduce turnover intention. Good organizational commitment results in a good relationship between employees and the company. Therefore, organizational commitment has an important role in the sustainability of the company.

Ahakwa et al. (2021) found that increasing organizational commitment can be done through employee engagement, work environment, and job satisfaction. A good commitment can improve performance and buying interest in the company's products. Iqbal et al. (2021) added that commitment can also be increased through entrepreneurial orientation. Various literatures have emphasized the importance of organizational commitment, as increasing commitment is an important responsibility and can optimize employee performance (Iqbal et al. 2021; Ahakwa et al. 2021). Companies with good organizational commitment will trigger good employee performance so that people's buying interest in the products sold will increase. Nguyen \& Tu (2020) argued that organizational commitment is a spiritual relationship between employees and organizations or companies that are able to reduce work risks caused by employees, in the sense that with commitment, employee performance is getting better. Chen et al. (2021) described the concept of trust, commitment and buying interest. It was found that trust is able to grow commitment and commitment is able to grow buying interest. The relationship between commitment and purchase intention is also supported by several previous studies such as Ahakwa et al. (2021; Ma et al. 2021; 
Iqbal et al. 2021; Abduloh et al. 2020).

$\mathrm{H}_{5}$ : Organizational commitment has a positive and significant effect on purchase intention.

\section{Research Method}

This study is a quantitative study that analyzes the relationship between 4 variables, namely perceived CSR, corporate reputation, organizational commitment, and purchase intention. The population in this study are employees of companies engaged in the cement industry in Indonesia. From the total population, 310 samples were taken. The data in this study are primary data taken through questionnaires distribution and analyzed using the Structural Equation Model (SEM) method with SmartPLS software.

The variables in this study are measured using 19 indicators which consist of 9 indicators for the perceived CSR variable, 3 indicators for the corporate reputation variable, 3 indicators for the organizational commitment variable, and 4 indicators for the purchase intention variable. In detail, the indicators in this study are as follows: (1) Perceived CSR is measured with 9 indicators as follows (Bianchi et al. 2019): (a) The brand/company treats employees very well; (b) The brand/company is socially responsible; (c) The brand/company helps civil society organizations in the community; (d) The brand/company is committed to ecological issues; (e) The brand/company returns some of what it has received to society; (f) The brand/company act thinking about society; (g) The brand/company integrates philanthropic contributions in their business activities; (h) The brand/company behaves honestly with their customers; and (i) The brand/company respect the legal regulations. (2) Corporate reputation is measured with 3 indicators as follows (Bianchi et al., 2019): (a) The brand/company is one of the best in the sector; (b) The brand/company is well established; and (c) The brand/company is well respected. (3) Organizational Commitment is measured with 3 indicators as follows (Kim et al., 2018): (a) I feel a strong sense of belonging to my organization; (b) I feel personally attached to my work organization; (c) I really feel that problems faced by my organization are also my problems. (4) Purchase Intention is measured with 4 indicators as follows (Bianchi et al., 2019): (a) I will purchase brand/company the next time I need a product; (b) It is very likely that I will buy that brand/company; (c) Definitely, I will buy some product of that brand/company; and (d) I will recommend the product to other people.

\section{Result}

\subsection{Respondent Characteristics}

The data in this study were obtained through questionnaire distribution. A total of 350 questionnaires were distributed, and 310 were returned and filled out correctly. Of the 310 respondents analyzed, it was found that the majority of respondents were male, amounting to 267 respondents or $86.1 \%$ of the total respondents. As for the age of the majority of respondents in this study, the age range between $25-35$ years is 170 respondents and the age range between $36-45$ years is as many as 110 respondents. Furthermore, from the characteristics of the respondents based on the latest education, it is known that the majority of respondents have the latest education of bachelor, which is 211 respondents, while 99 respondents have the last education senior high school.

\subsection{Outer Model Evaluation}

The outer model analysis in this study is consisted of validity and reliability tests. The validity test used in this study is convergent validity and construct validity. The results of the convergent validity test show that there are 4 indicators that must be dropped because they have a loading factor value below the standard value of 0.7 , namely the CSR1, CSR2, CSR 3 , and CSR4 indicators. After the invalid indicators are dropped, they are analyzed again and give the results as shown in Table 1. 
Table 1: Validity Analysis

\begin{tabular}{|l|c|c|}
\hline Indicators & Loading Factor & \multirow{2}{*}{ AVE } \\
\hline CSR5 & 0.778 & \multirow{2}{*}{0.648} \\
\hline CSR6 & 0.831 & \\
\hline CSR & 0.806 & \\
\hline CSR8 & 0.771 & \multirow{2}{*}{0.772} \\
\hline CSR9 & 0.837 & \\
\hline CR1 & 0.860 & \multirow{2}{*}{0.690} \\
\hline CR2 & 0.898 & \\
\hline CR3 & 0.877 & \\
\hline OC1 & 0.787 & \multirow{2}{*}{0.732} \\
\hline OC2 & 0.893 & \\
\hline OC 3 & 0.808 & \\
\hline PI1 & 0.895 & \\
\hline PI2 & 0.905 & \\
\hline PI3 & 0.899 & \\
\hline PI & 0.708 & \\
\hline
\end{tabular}

The indicator validity standard is the loading factor value of $>0.7$, while the variable validity standard is the AVE value of $>0.5$. Table 1 shows that all indicators have a loading factor value according to the standard and all variables have also been declared valid. Furthermore, the results of the reliability test are shown in Table 2.

Table 2: Reliability Analysis

\begin{tabular}{|l|c|c|}
\hline & Cronbach's Alpha & Composite Reliability \\
\hline Perceived CSR & 0.864 & 0.902 \\
\hline Corporate Reputation & 0.852 & 0.910 \\
\hline Organizational Commitment & 0.774 & 0.869 \\
\hline Purchase Intention & 0.877 & 0.915 \\
\hline
\end{tabular}

According to Hair et al. (2019), a construct can be said to be reliable if it has Cronbach's alpha value of 0.6 and the Composite reliability value of 0.7 . Table 2 shows that in this study, all of the constructs have a Cronbach's alpha value of 0.6 and a Composite reliability value of 0.7 , thus all constructs are reliable since it has met the requirement from Hair et al. (2019), and each construct in the research model has internal consistency according to the results of reliability test.

\subsection{Inner Model Evaluation}

Testing of the inner model or structural model is carried out to predict causal relationships between variables or to test hypotheses. This test can be seen through the results of the coefficient of determination, goodness of fit, and hypothesis testing. When the significant relationship between variables is known, then the hypothesis related to the variables used in this study can be analyzed. Hypothesis testing is carried out by bootstrapping. The PLS bootstrapping output in this research model are presented in Figure 1. 




Figure 1: Inner Model

\section{$4.4 \quad R$ Square}

The coefficient of determination is presented in the R-square table by multiplying the R-square value by $100 \%$. If the result is more than $67 \%$, then it indicates a good coefficient of determination. If the result is less than $67 \%$ but more than $33 \%$, it indicates a moderate coefficient of determination. If it is less than $33 \%$ but more than $19 \%$, it indicates a weak coefficient of determination (Chin, 1998; Ghozali, 2008). The coefficient of determination test results show that all variables have a good coefficient of determination as presented in Table 3.

Table 3: R-Square

\begin{tabular}{|l|c|c|}
\hline & R Square & R Square Adjusted \\
\hline Corporate Reputation & 0.549 & 0.548 \\
\hline Organizational Commitment & 0.459 & 0.457 \\
\hline Purchase Intention & 0.676 & 0.673 \\
\hline
\end{tabular}

As shown on the R-square value in table 3, the coefficient of determination of each variable is 0.549 or $54.9 \%$ for the corporate reputation variable, 0.459 or $45.9 \%$ for the organizational commitment variable and 0.676 or $67.6 \%$. for the purchase intention variable. These results indicate that all endogenous variables in this study have a moderate coefficient of determination.

\subsection{Goodness of Fit}

PLS can also identify global optimization criteria to determine the goodness of fit model (GoF). The Gof index is calculated from the square root of the average communality index and the average Rsquare value. $\mathrm{GoF}=0.1$ means small, $\mathrm{GoF}=0.25$ means medium, $\mathrm{GoF}=0.36$ means large. $\mathrm{GOF}$ value can be calculated using the formula of Goodness of fit $=\sqrt{A V E X R^{2}}$. The calculation results are shown in Table 4. 
Table 4: Results of Goodness of Fit Model (GoF)

\begin{tabular}{|l|c|c|}
\hline Construct & AVE & R Square \\
\hline Perceived CSR & 0.648 & \\
\hline Corporate Reputation & 0.772 & 0.549 \\
\hline Organizational Commitment & 0.690 & 0.459 \\
\hline Purchase Intention & 0.732 & 0.676 \\
\hline Average & 0,710 & 0,561 \\
\hline Gof & \multicolumn{2}{|c|}{0,631} \\
\hline
\end{tabular}

Based on Table 16, it can be seen that the GoF value of the model reaches 0.631 , which is greater than 0.36 , thus the model is included in the large category (large).

\subsection{Hypothesis Test}

Hair et al. (2019) stated that the measurement items used are significant if the T-statistics value is greater than 1.96 and the p-value is less than 0.05 at the $5 \%$ significance level. Meanwhile, the parameter coefficient that shows the direction of the effect can be known by looking at the positive or negative value of the original sample (Ghozali, 2008). The results of hypothesis testing are shown in Table 5 .

Table 5: Path Coefficients

\begin{tabular}{|l|c|c|c|}
\hline & Original Sample (O) & T Statistics (|O/STDEV|) & P Values \\
\hline Perceived CSR -> Corporate Reputation & 0.741 & 26.960 & 0.000 \\
\hline Perceived CSR -> Organizational Commitment & 0.677 & 20.001 & 0.000 \\
\hline Perceived CSR -> Purchase Intention & 0.176 & 3.030 & 0.003 \\
\hline Corporate Reputation -> Purchase Intention & 0.173 & 3.195 & 0.001 \\
\hline $\begin{array}{l}\text { Organizational Commitment -> Purchase } \\
\text { Intention }\end{array}$ & 0.545 & 10.733 & \multirow{2}{*}{0.000} \\
\hline
\end{tabular}

Table 5 shows that hypothesis 1 which states that perceived CSR has a positive and significant effect on corporate reputation is supported. These results are indicated by the positive original sample value, namely 0.741 , the t-statistic value of $\geq 1.96$, namely 26.960 and the $p$-value of $\leq 0.05$, which is o.ooo. Hypothesis 2 which states that perceived CSR has a positive and significant effect on organizational commitment is supported. These results are indicated by a positive original sample value of 0.677 , the t-statistic value of $\geq 1.96$, which is 20.001 and the $p$-value of $\leq 0.05$, which is 0.000 . Hypothesis 3 which states that perceived CSR has a positive and significant effect on purchase intention is supported. These results are indicated by a positive original sample value that is 0.176 , the t-statistic value of $\geq 1.96$, which is 3.030 and a p-value of $\leq 0.05$, which is 0.003 . Furthermore, hypothesis 4 which states that corporate reputation has a positive and significant effect on purchase intention is supported. These results are indicated by a positive original sample value of 0.173 , the tstatistic value of $\geq 1.96$, which is 3.195 and the p-value of $\leq 0.05$, which is 0.001 . And hypothesis 5 which states organizational commitment has a positive and significant effect on purchase intention is supported. These results are indicated by the positive original sample value, namely 0.545 , the $t$ statistic value of $\geq 1.96$, which is 10.733 and the p-value of $\leq 0.05$, which is 0.000 .

\section{Discussion}

This study analyzes the important role of CSR in improving several crucial aspects in companies, especially those engaged in the Indonesian cement industry. Some of these aspects include 
reputation, organizational commitment, and purchase intention. Of the 4 variables analyzed in this study, 5 hypotheses were formulated which were analyzed using the structural equation model method with SmartPLS software. Based on the results of the study, is empirically proven that the increase in perceived CSR can significantly boost the corporate reputation. The same findings from Aved et al. (2020; Aksak et al., 2016; Vishwanathan et al. 2020; Rehman et al. 2020; Kucharska, 2020) stated that CSR has an important role in improving company reputation. This study proposes an optimal increase in CSR activities. These activities are part of the social and environmental support provided by the company. CSR activities consist of four dimensions, namely discretionary, ethical, legal, and economic CSR (Lee, 2020). The implementation of good CSR activities will foster prestige for employees. This prestige arises because the corporate reputation increases in the public eyes' (Lee, 2020). Regarding the important role of CSR, the results of hypothesis 2 testing in this study are also supported, so that it is proven that in addition to increasing the corporate reputation, CSR is also able to increase organizational commitment. The relationship between CSR and organizational commitment is also supported by some literature (Ahmad et al., 2020; Bianchi et al. 2019; Roudaki \& Arsland, 2017). George et al. (2020) added that the relationship between CSR and organizational commitment can be mediated by organizational trust and organizational identification. In addition, Konte et al. (2020) found that there is a relationship between CSR and organizational commitment. Organizational commitment that is formed from optimal CSR management will improve good relations between employees and the company. These conditions will form optimal and effective employee performance. Various literatures agree that CSR is a company strategy in creating longterm profits (Bianchi et al. 2019). Therefore, companies, especially those engaged in the cement industry, should pay close attention to the allocation of CSR, ensure proper CSR targets, provide many benefits, and be able to create a good image and relationship with the surrounding environment.

This study also proves that purchase intention can be increased through good perceived CSR. This finding is supported by several previous studies by Dang et al. (2020; Hoang et al. 2020; Cheng et al. 2021; Gupta et al. 2021). Alniacik et al. (2020) found that the relationship between CSR and purchase intention can be strengthened by the presence of a personal value orientation. A different finding was put forward by Gupta \& Wadera (2020) that in the fast-moving-consumers-goods sector CSR does not have a significant impact on purchase intention. The results of the overall analysis show that perceived CSR is able to provide three major benefits for the company, namely increased reputation, improved organizational commitment and increased buying interest. This study emphasizes the importance of CSR for companies. Funds issued by companies in the form of CSR will be able to provide greater profits, especially in the long term. Furthermore, this study found the evidence that in the cement industry in Indonesia, reputation is able to increase people's purchase intention. The same finding was also shown by Balakrishnan \& Foroudi (2020; Qalati et al. 2021; Javed et al. 2020; Bianchi et al. 2019). Although Kim \& Oh (2020) found that in the fashion industry, especially sports fashion, the corporate reputation has a weaker impact than the sustainability level. Companies really expect a positive reputation, because in addition to improving performance and purchase intention, a positive reputation can reduce or even eliminate the effects of a negative reputation on other aspects of the company (Jung \& Seock, 2016). Therefore, various efforts must be made by the company to improve its reputation. In this digital era, the fate of a company is very dependent on reputation. The rapid spread of information allows information to trigger the bankruptcy of a business or even trigger an increase in company profits (Javed et al. 2020). Regarding efforts to increase purchase intention, hypothesis 5 in this study is also supported. It is proven that organizational commitment is able to have a significant influence on purchase intention. Nguyen \& $\mathrm{Tu}(\mathbf{2 0 2 0})$ argued that organizational commitment is a spiritual relationship between employees and organizations or companies that are able to reduce work risks caused by employees, in the sense that with commitment, employee performance is getting better.

The relationship between commitment and purchase intention is also supported by several previous studies such as Ahakwa et al. (2021; Ma et al. 2021; Iqbal et al. 2021; Abduloh et al. 2020). 
Good organizational commitment means a good relationship between employees and the company. Companies must ensure that employee rights are granted and employees must also ensure that their work and responsibilities are carried out properly.

\section{Conclusion}

This study analyzes 4 variables, namely perceived CSR, corporate reputation, organizational commitment and purchase intention in companies engaged in the Indonesian cement industry. From these variables, 5 hypotheses were formulated and analyzed using the structural equation model method. The results of the analysis show that all hypotheses in this study are supported. Hypothesis 1 which states that perceived CSR has a positive and significant effect on corporate reputation is supported. Hypothesis 2 which states that perceived CSR has a positive and significant effect on organizational commitment is supported. Hypothesis 3 which states that perceived CSR has a positive and significant effect on purchase intention is supported. Furthermore, hypothesis 4 which states that corporate reputation has a positive and significant effect on purchase intention is supported. And hypothesis 5 which states organizational commitment has a positive and significant effect on purchase intention is supported.

\section{Managerial Implication}

This study provides some managerial advice for companies engaged in the cement industry and other related companies. First, this study recommends that companies should pay serious attention to the allocation of CSR. Starting from the CSR budget that must be optimized to the allocation with the right target. This is empirically proven to be able to provide three major benefits for the company, namely an increased reputation, improved organizational commitment, and increased buying interest. This study emphasizes the importance of CSR for companies. Funds issued by companies in the form of CSR will be able to provide greater profits, especially in the long term.

\section{Aknowledgment}

We express our gratitude to PT. Indocement who have funded this study as a part of the CSR.

\section{Reference}

Abduloh, O. A., Juhadi, A. S., Mohammad Syaifuddin, B. E., Wahid Wachyu Adi Winarto, N. A., Mubtadi, W., Hendri Hermawan Adinugraha, A. P., ... \& Muhammad Masruri, N. A. (2020). Effect of Organizational Commitment toward Economical, Environment, Social Performance and Sustainability Performance of Indonesian Private Universities. PalArch's Journal of Archaeology of Egypt/Egyptology, 17(7), 6951-6973.

Ahakwa, I., Yang, J., Tackie, E. A., \& Atingabili, S. (2021). The Influence of Employee Engagement, Work Environment and Job Satisfaction on Organizational Commitment and Performance of Employees: A Sampling Weights in PLS path Modelling. SEISENSE Journal of Management, 4(3), 34-62.

Ahmad, R., Ahmad, S., Islam, T., \& Kaleem, A. (2020). The nexus of corporate social responsibility (CSR), affective commitment and organisational citizenship behaviour in academia: A model of trust. Employee Relations: The International Journal. 42(1), 232-247.

Ahn, J., \& Kwon, J. (2020). CSR perception and revisit intention: the roles of trust and commitment. Journal of Hospitality and Tourism Insights. 3(5), 607-623.

Aksak, E. O., Ferguson, M. A., \& Duman, S. A. (2016). Corporate social responsibility and CSR fit as predictors of corporate reputation: A global perspective. Public Relations Review, 42(1), 79-81.

Balakrishnan, J., \& Foroudi, P. (2020). Does corporate reputation matter? Role of social media in consumer intention to purchase innovative food product. Corporate Reputation Review, 23(3), 181-200.

Bianchi, E., Bruno, J. M., \& Sarabia-Sanchez, F. J. (2019). The impact of perceived CSR on corporate reputation and purchase intention. European journal of management and business economics. 28(3), 206-221. 
Cheng, G., Cherian, J., Sial, M. S., Mentel, G., Wan, P., Álvarez-Otero, S., \& Saleem, U. (2021). The relationship between csr communication on social media, purchase intention, and e-wom in the banking sector of an emerging economy. Journal of Theoretical and Applied Electronic Commerce Research, 16(4), 1025-1041.

Chen, Y., Liu, M. T., Liu, Y., Chang, A. W. Y., \& Yen, J. (2021). The influence of trust and relationship commitment to vloggers on viewers' purchase intention. Asia Pacific Journal of Marketing and Logistics. (a head of print)

Chin, W. W. (1998). The partial least squares approach to structural equation modeling. Modern methods for business research, 295(2), 295-336

Choi, D., Lee, K. H., \& Hur, H. (2020). Social enterprises' social orientation: The impact on the organizational commitment of employees. Journal of Public and Nonprofit Affairs, 6(1), 44-62.

Cyfert, S., Glabiszewski, W., \& Zastempowski, M. (2021). Impact of Management Tools Supporting Industry 4.o on the Importance of CSR during COVID-19. Generation Z. Energies, 14(6), 1642.

Dang, Van., Nguyen, N., \& Wang, J. (2020). Consumers' perceptions and responses towards online retailers' CSR. International Journal of Retail E Distribution Management. 48(12), 1277-1299.

Divya, T., \& Evanita, S. (2021). The influence of social media and celebrity endorsers on culinary purchase intention by viral marketing as a mediating variable. Operations Management and Information System Studies, 1(1), 41-50.

Elkington, J. (1997). The triple bottom line in Environmental management: Readings and cases, Sage, Los Angles.

George, N. A., Aboobaker, N., \& Edward, M. (2020). Corporate social responsibility and organizational commitment: effects of CSR attitude, organizational trust and identification. Society and Business Review. $15(3), 255-272$.

Ghozali, Imam. (2008). Structural Equation Modelling, Edisi II, Universitas. Diponegoro, Semarang.

Gupta, S., Nawaz, N., Alfalah, A. A., Naveed, R. T., Muneer, S., \& Ahmad, N. (2021). The Relationship of CSR Communication on Social Media with Consumer Purchase Intention and Brand Admiration. Journal of Theoretical and Applied Electronic Commerce Research, 16(5), 1217-1230.

Hair Jr, J. F., Black, W. C., Babin, B. J., \& Anderson, R. E. (2019). Multivariate Data Analysis (Eighth Edition). Hampshire: Cengage Learning.

Henry, L. A., Buyl, T., \& Jansen, R. J. (2019). Leading corporate sustainability: The role of top management team composition for triple bottom line performance. Business Strategy and the Environment, 28(1), 173-184.

Hoang, X. L., Nguyen, T. K. C., LY, H. M., Luong, T. T., \& NGUYEN, T. T. Q. (2020). The moderating role of CSR associations on the link between brand awareness and purchase intention. The Journal of Asian Finance, Economics, and Business, $7(6), 233-240$.

Hofman, P. S., \& Newman, A. (2014). The impact of perceived corporate social responsibility on organizational commitment and the moderating role of collectivism and masculinity: Evidence from China. The International Journal of Human Resource Management, 25(5), 631-652.

Iqbal, S., Moleiro Martins, J., Nuno Mata, M., Naz, S., Akhtar, S., \& Abreu, A. (2021). Linking entrepreneurial orientation with innovation performance in SMEs; the role of organizational commitment and transformational leadership using smart PLS-SEM. Sustainability, 13(8), 4361.

Javed, M., Rashid, M. A., Hussain, G., \& Ali, H. Y. (2020). The effects of corporate social responsibility on corporate reputation and firm financial performance: Moderating role of responsible leadership. Corporate Social Responsibility and Environmental Management, 27(3), 1395-1409.

Jung, N. Y., \& Seock, Y. K. (2016). The impact of corporate reputation on brand attitude and purchase intention. Fashion and Textiles, 3(1), 1-15.

Khaskheli, A., Jiang, Y., Raza, S. A., Qureshi, M. A., Khan, K. A., \& Salam, J. (2020). Do CSR activities increase organizational citizenship behavior among employees? Mediating role of affective commitment and job satisfaction. Corporate Social Responsibility and Environmental Management, 27(6), 2941-2955.

Kim, B. J., Nurunnabi, M., Kim, T. H., \& Jung, S. Y. (2018). The influence of corporate social responsibility on organizational commitment: The sequential mediating effect of meaningfulness of work and perceived organizational support. Sustainability, 10(7), 2208.

Kim, Y., \& Oh, K. W. (2020). Effects of Perceived Sustainability Level of Sportswear Product on Purchase Intention: Exploring the Roles of Perceived Skepticism and Perceived Brand Reputation. Sustainability, 12(20), 8650.

Konte, A. G., Xiaohui, L., \& Younas, A. (2020, January). Employee's CSR perceptions and their organizational commitment: an analysis of the moderating role of need to belong and the mediating role of Person Organization Fit. In Proceedings of the 2020 4th International Conference on Management Engineering, Software Engineering and Service Sciences (pp. 201-210).

Kucharska, W. (2020). Employee commitment matters for CSR practice, reputation and corporate brand performance-European model. Sustainability, 12(3), 940-956. 
Lee, Y. (2020). Toward a communality with employees: The role of CSR types and internal reputation. Corporate Reputation Review, 23(1), 13-23.

Ma, J., Hong, J., Yoo, B., \& Yang, J. (2021). The effect of religious commitment and global identity on purchase intention of luxury fashion products: A cross-cultural study. Journal of Business Research, 137, 244-254.

Motilewa, D. B., \& Worlu, R. E. (2015). Corporate social responsibility as a tool for gaining competitive advantage. International Journal of Multidisciplinary Research and Review. 1(1),16-24

Nguyen, T. H., \& Tu, V. B. (2020). Social responsibility, organizational commitment, and organizational performance: Food processing enterprises in the Mekong River Delta. The Journal of Asian Finance, Economics, and Business, $7(2)$, 309-316.

Nguyen, T., Pham, T., Le, Q., \& Bui, T. (2020). Impact of corporate social responsibility on organizational commitment through organizational trust and organizational identification. Management Science Letters, 10(14), 3453-3462.

Pham, H. S. T., \& Tran, H. T. (2020). CSR disclosure and firm performance: The mediating role of corporate reputation and moderating role of CEO integrity. Journal of Business Research, 120, 127-136.

Rehman, Z. U., Khan, A., \& Rahman, A. (2020). Corporate social responsibility's influence on firm risk and firm performance: the mediating role of firm reputation. Corporate Social Responsibility and Environmental Management, 27(6), 2991-3005.

Roudaki, J. \& Arslan (2017). Impact of perceived CSR on organizational commitment: A perspective of service employees. Austin J Bus Adm Manage, 1(3), 1014.

Gupta, S. S., \& Wadera, D. (2020). Impact of cause-affinity and CSR fit on consumer purchase intention. Society and Business Review. 16(1), 26-50.

Taghian, M., D'Souza, C., \& Polonsky, M. (2015). A stakeholder approach to corporate social responsibility, reputation and business performance. Social Responsibility Journal. 11(2), 340-363.

Tangngisalu, J., Mappamiring, M., Andayani, W., Yusuf, M., \& Putra, A. H. P. K. (2020). CSR and firm reputation from employee perspective. The Journal of Asian Finance, Economics, and Business, 7(10), 171-182.

Verčič, A. T., \& Corić, D. S. (2018). The relationship between reputation, employer branding and corporate social responsibility. Public Relations Review, 44(4), 444-452.

Vishwanathan, P., van Oosterhout, H., Heugens, P. P., Duran, P., \& Van Essen, M. (2020). Strategic CSR: A concept building meta-analysis. Journal of Management studies, 57(2), 314-350. 